\title{
Incidence of postharvest decays on cultivars of pear, apricot, sour cherry and peach under two storage conditions
}

\author{
Holb, I.J. ${ }^{1}$, Soltész, M. ${ }^{1,2}$, Nyéki, J. ${ }^{1}$ \& Szabó, Z. ${ }^{1}$ \\ ${ }^{1}$ University of Debrecen Centre for Agricultural and Applied Economic Sciences, \\ H-4032 Debrecen, Böszörményi str. 138., Hungary holb@agr.unideb.hu \\ ${ }^{2}$ College of Kecskemét, Faculty of Horticulture, H-6000 Kecskemét, Erdei Ferenc square 1-3.
}

\begin{abstract}
Summary: In this two-year study, postharvest decays of pear, apricot, sour cherry and peach cultivars under two storage methods (TC and CA) were determined after four monthes storage periods; and then causal agents of postharvest decays of two pear cultvars were idenfified under traditional cold storage conditions. Results showed that postharvest decay was lower under controlled atmosphere compared to traditional cold one. Decay was lower on pear and the largest deacy occured on peach and apricot cultivars. Cultivars of fruit species also showed differences in incidence of fruit decays. Incidence of decays was independent on year effect. Under controlled atmosphere, postharvest decay ranged between 0 an $8 \%$ for pear, and between 5 and 12\% for apricot, and between 6 and 11\% for sour cherry, and between 5 and $15 \%$ for peach. Under traditional cold storage, postharvest decay ranged between 16 an $21 \%$ for pear, and between 15 and $39 \%$ for apricot, and between 10 and 22\% for sour cherry, and between 19 and 33\% for peach. Incidence of pear fruit damage ranged between 7.5 and $12.3 \%$. Most damage started from injured fruit or wounded fruit. Five types of damage occurred ont he pear fruits in both years: Penicillium spp., Monilinia spp., Chondrostereum spp., other pathogens and mechanical injury. The most common damage was caused by Penicillium spp., Monilina spp. and Chondrostereum spp. On both pear cultivars in both years.
\end{abstract}

Key words: postharvest decay, Monilinia spp., Penicillium spp., traditional cold storage, controlled atmosphere

\section{Introduction}

Among fruit diseases, those fungal pathogens are of great importance which cause fruit rot. These are mainly fungi of Penicillium, Fusarium, Aspergillus, Botrytis, and Monilinia spp. Among fruit rot pathogens Monilinia spp. (mainly $M$. fructigena and M. laxa) the most important fruit rot disease (Batra, 1991; Holb, 2004; Balla et al., 2008). Since the pathogens are wound parasites, it appears on the fruits at injuries after hail or strong pest damage. Brown rotting of fruits starts and then grey conidiophores appears on their surface. The fruits often mummify and stay on the tree. The primary inoculum sources of the disease are the dead woody parts and the fruit mummies. The disease can also cause significant damages during storage. Its host plants include the stone fruit species (Holb, 2004, 2006).

Under storage conditions, decreasing temperature reduced the growth of Monilinia spp. (e.g. Byrde \& Willetts, 1977, Tian et al., 2001). Tian et al. (2001) showed that growth of $M$. fructicola on sour cherry significantly declined with increased $\mathrm{CO}_{2}$ concentrations at above $15 \%$ and the fungus was more sensitive to increasing $\mathrm{CO}_{2}$ concentrations at lower temperature ranges. As apple stored such conditions as traditional cold (TC) and controlled atmosphere (CA) storage methods, they may affect postharvest rot of apple caused by $M$. fructigena. In addition, temporal dynamics pattern of brown rot development may differ in these storage methods under a long-term storage conditions.

The aims of this two-year study was firstly, to determine postharvest decays of pear, apricot, sour cherry and peach cultivars under two storage methods (TC and CA); and secondly, to identify causal agents of postharvest decays of two pear cultvars under traditional cold storage conditions.

\section{Materials and methods}

\section{Orchard site and disease assessments}

The study was performed at Nagykanizsa in a commercial fruit orchards including pear, apricot, sour cherry and peach fruits. The following pear cultivars were used in the study: Conference, Bosc kobak and Williams. In addition, three apricot, three sour cherry and three peach cultivars were used in the study in the following order: Bergeron, Ceglédi óriás, and Pincot; Érdi bőtermő, Újfehértói fürtös, and Debreceni bőtermő; Sweet Red, Andosa, and Suncrest. Pear cultivars were stored under traditional cold and under controlled atmosphere 
storage conditions for four monthes while stone fruit cultivars were stored only for four weeks. Two experiments were performed. In experiment one, all cultivars were used under both storage conditions and incidence of postharvest deacys was observed. In experiment two, only two pear cultivars (Bosc kobak and Williams) were used but causal agents of postharvest decays were identified under traditional cold storage. Assessments were made in 2010 and 2011. All assessments were made on 50 fruit per cultvars in storage conditions in four replications. Incidence was calculated as percentage of diseased fruit or causal agents. Data for each postharvest deacy, cultivar and storage methids were averaged and then analysed by using analyses of variance in Excel PC programme.

\section{Results and discussion}

\section{Incidence of postharvest decay}

Results showed that postharvest decay was lower under controlled atmosphere compared to traditional cold one (Tables 1 and 2). Decay was lower on pear and the largest deacy occured on peach and apricot cultivars. Cultivars of fruit species also showed differences in incidence of fruit decays. Incidence of decays was independent on year effect. Under controlled atmosphere, postharvest decay ranged between 0 an $8 \%$ for pear, and between 5 and $12 \%$ for apricot, and between 6 and $11 \%$ for sour cherry, and between 5 and $15 \%$ for peach. Under traditional cold storage, postharvest decay ranged between 16 an $21 \%$ for pear, and between 15 and $39 \%$ for apricot, and between 10 and $22 \%$ for sour cherry, and between 19 and $33 \%$ for peach. Fruit rot caused by Monilinia and Penicillium was the most common

Table 1. Incidence of postharvest deacy of fruit of four fruit species under two storage conditions (Nagykanizsa, 2010)

\begin{tabular}{|c|c|c|}
\hline & Controlled atmosphere & Traditional cold \\
\hline \multicolumn{3}{|l|}{ Pear } \\
\hline Conference & 7 & 18 \\
\hline Bosc kobak & 0 & 16 \\
\hline Williams & 8 & 21 \\
\hline \multicolumn{3}{|l|}{ Apricot } \\
\hline Bergeron & 9 & 35 \\
\hline Ceglédi óriás & 10 & 30 \\
\hline Pincot & 7 & 18 \\
\hline \multicolumn{3}{|l|}{ Sour cherry } \\
\hline Érdi bőtermő & 8 & 19 \\
\hline Újfehértói fürtös & 10 & 17 \\
\hline Debreceni bőtermő & 6 & 11 \\
\hline \multicolumn{3}{|l|}{ Peach } \\
\hline Sweet Red & 10 & 27 \\
\hline Andosa & 7 & 20 \\
\hline Suncrest & 6 & 19 \\
\hline
\end{tabular}

decay on pear fruit while fruit rot caused by Monilinia was the most common decay on apricot, sour cherry, and peach.

Table 2 Incidence of postharvest deacy of fruit of four fruit species under two storage conditions (Nagykanizsa, 2011)

\begin{tabular}{|c|c|c|}
\hline & Controlled atmosphere & Traditional cold \\
\hline \multicolumn{3}{|l|}{ Pear } \\
\hline Conference & 5 & 19 \\
\hline Bosc kobak & 0 & 16 \\
\hline Williams & 8 & 18 \\
\hline \multicolumn{3}{|l|}{ Apricot } \\
\hline Bergeron & 5 & 39 \\
\hline Ceglédi óriás & 12 & 26 \\
\hline Pincot & 3 & 15 \\
\hline \multicolumn{3}{|l|}{ Sour cherry } \\
\hline Érdi bőtermő & 7 & 22 \\
\hline Újfehértói fürtös & 11 & 19 \\
\hline Debreceni bőtermő & 7 & 10 \\
\hline \multicolumn{3}{|l|}{ Peach } \\
\hline Sweet Red & 15 & 33 \\
\hline Andosa & 9 & 24 \\
\hline Suncrest & 5 & 22 \\
\hline
\end{tabular}

\section{Types of postharvest damage on pear cultivars}

Incidence of pear fruit damage ranged between 7.5 and 12.3\% (Tables 3 and 4). Most damage started from injured fruit or wounded fruit. Five types of damage occurred ont he pear fruits in both years: Penicillium spp., Monilinia spp., Chondrostereum spp., other pathogens and mechanical injury. The most common damage was caused by Penicillium spp., Monilinia spp. and Chondrostereum spp. On both pear cultivars in both years.

Table 3. Types of postharvest damage on two pear cultivar uner traditional cold storage condition (Nagykanitsa, 2010)

\begin{tabular}{|l|c|c|}
\hline & Bosc kobak & Williams \\
\hline Penicillium spp. & 2.4 & 3.8 \\
\hline Monilinia spp. & 1.5 & 4.2 \\
\hline Chondrostereum spp. & 5.2 & 1.1 \\
\hline Other pathogens & 0.7 & 0.9 \\
\hline Mechanical injury & 0.4 & 0.5 \\
\hline
\end{tabular}

Table 4. Types of postharvest damage on two pear cultivar uner traditional cold storage condition (Nagykanitsa, 2011)

\begin{tabular}{|l|c|c|}
\hline & Bosc kobak & Williams \\
\hline Penicillium spp. & 3.7 & 4.9 \\
\hline Monilinia spp. & 1.9 & 5.2 \\
\hline Chondrostereum spp. & 6.3 & 2.2 \\
\hline Other pathogens & 1.7 & 2.9 \\
\hline Mechanical injury & 0.6 & 0.7 \\
\hline
\end{tabular}




\section{Acknowledgements}

Support of the Ministry of Agriculture and Rural Development highly acknowledged. The study was partly supported by the Hungarian Scientific Research Fund (OTKA K78399) and a János Bolyai Research Fellowship awarded to I. Holb and NFÜ TECH_08-A3/2-20080373grant.

\section{References}

Balla, B., Abonyi, F., Drén, G., Barkaszi, I. \& Holb, I.J. (2008): Effect of three storage methods on fruit decay and brown rot of apple. Cereal Res. Commun. 36: 799-802.
Batra, L. R. (1991): World species of Monilinia (Fungi): Their ecology, biosystematics and control. Mycologia Memoir, No. 16. J. Cramer, Berlin, Germany.

Byrde, R.J.W. \& Willetts, H.J. (1977): The brown rot fungi of fruit. Their biology and control. Pergamon Press, Oxford, UK.

Holb, I.J. (2004): The brown rot fungi of fruit crops (Monilinia spp.) III. Important features of their disease control (Review). International Journal of Horticultural Science 10 (4): 31-48.

Holb, I.J. (2006): Possibilities of brown rot management in organic stone fruit production in Hungary. International Journal of Horticultural Science 12 (3): 87-92.

Tian, S.P., Fan, Q., Xu, Y., Wang Y. \& Jiang A.L. (2001): Evaluation of the use of high $\mathrm{CO}_{2}$ concentrations and cold storage to control Monilinia fructicola on sweet cherries. Postharvest Biol. Technol. 22: 53-60. 